\title{
CELL PROLIFERATION IN THE UTERUS OF THE GUINEA-PIG
}

\author{
S. N. MEHROTRA AND G. A. FINN \\ Department of Physiology, Royal Veterinary College, London NW1 0TU
}

(Received 19th Fuly 1973)

Summary. The pattern of cell division in the uterus of the guinea-pig has been studied, during the oestrous cycle (with and without mating) and after treatment of ovariectomized animals with ovarian hormones.

During the oestrous cycle, there were many luminal epithelial cells undergoing mitosis just before and after the time of ovulation whilst mitosis counts in the glandular epithelium were maximal about 4 days after ovulation. In the stroma, cell division reached a peak on Day 6 of the cycle, just before the expected time of implantation.

In ovariectomized animals, mitosis was stimulated by exogenous oestradiol, indicating that epithelial mitosis during the cycle is associated with follicular oestrogen secreted during pro-oestrus. Progesterone alone stimulated only a few mitoses in the stroma, but the number was increased considerably by the addition of a small quantity of oestradiol. This indicates that luteal progesterone cannot be solely responsible for the very high level of stromal mitosis on Days 5 and 6 of the cycle and suggests that some oestrogen is also being secreted at this time.

\section{INTRODUCTION}

Among common laboratory rodents, the guinea-pig is unusual in having a long oestrous cycle with an extended luteal phase. Implantation takes place during the luteal phase, although there are indications that the progesterone requirement for implantation is very small (Deanesly, 1960). There is also evidence that nidatory oestrogen is not necessary for successful implantation in this species.

The patterns of cell proliferation in the tissues of the endometrium associated with the preparation of the uterus for implantation have been studied extensively in mice (Finn \& Martin, 1967) and rats (Clark, 1971; Chaudhury \& Sethi, 1970) and the hormonal control has been worked out in some detail (Martin \& Finn, 1968).

In view of the apparent difference in the hormonal requirements for implantation in the guinea-pig compared with the rat and mouse and the extended luteal phase during the cycle, the present study was undertaken. The aims of the study were firstly to determine the pattern of mitosis in the endometrium during the oestrous cycle, with and without mating, and secondly to observe the influence of ovarian hormones on cell division in the uterus of ovariectomized guinea-pigs. 


\section{MATERIALS AND METHODS}

Guinea-pigs were inspected daily for vaginal opening. The day on which the vagina was first patent was called Day 0 of the oestrous cycle. When pregnant animals were required, a male was placed with females at the first sign of vaginal opening and pregnancy was dated from the day of finding a vaginal plug (Day 1). Using this system of dating, the dates for the oestrous cycle and pregnancy are similar, thus making comparison simpler.

For the experiments involving the administration of hormones, the guineapigs were ovariectomized through the flank under ether anaesthesia and the hormones were injected subcutaneously dissolved in arachis oil. Colchicine at a dose rate of $4 \mathrm{mg} / \mathrm{kg}$ was administered intraperitoneally and the animals were killed $2 \mathrm{hr}$ later. The uteri were fixed in Bouin's fluid and sections were prepared in the usual way. The number of cells in mitosis in the various tissues of the uterus were then counted in a cross-section taken at random from each uterus.

\section{RESULTS}

Mitosis during the oestrous cycle

There was no evidence of mitosis in the luminal epithelium for most of the cycle, counts only being recorded on Days 0 to 3 and 14 (Table 1), presumably in response to rising oestrogen levels of the days preceding the opening

Table 1 Mitosis in uterine tissues of the guinea-pig during the oestrous cycle

\begin{tabular}{c|c|c|c}
\hline \multirow{3}{*}{ Day of cycle } & \multicolumn{3}{|c}{ Mean no. of mitoses \pm S.E. } \\
\cline { 2 - 4 } & Lumen & Glands & Stroma \\
\hline 0 & $25 \cdot 83 \pm 6 \cdot 64$ & $12 \cdot 33 \pm 2 \cdot 29$ & $2 \cdot 0 \pm 0 \cdot 51$ \\
1 & $22 \cdot 55 \pm 3 \cdot 23$ & $30 \cdot 43 \pm 2 \cdot 34$ & $5 \cdot 49 \pm 3 \cdot 79$ \\
2 & $19 \cdot 88 \pm 2 \cdot 23$ & $35 \cdot 21 \pm 6 \cdot 22$ & $7 \cdot 88 \pm 0 \cdot 22$ \\
3 & $28 \cdot 55 \pm 1 \cdot 61$ & $69 \cdot 106 \pm 38 \cdot 38$ & 0 \\
4 & 0 & $215 \cdot 52 \pm 22 \cdot 81$ & $31 \cdot 4 \pm 1 \cdot 75$ \\
5 & 0 & $52 \cdot 083 \pm 30 \cdot 96$ & $59 \cdot 6 \pm 5 \cdot 6$ \\
6 & 0 & $39 \cdot 12 \pm 6 \cdot 04$ & $70 \cdot 25 \pm 1.54$ \\
7 & 0 & $17 \cdot 69 \pm 3 \cdot 2$ & $51 \cdot 69 \pm 2 \cdot 65$ \\
8 & 0 & $0.0 \pm 3 \cdot 61$ & $20 \cdot 83 \pm 3 \cdot 75$ \\
9 to 13 & 0 & 0 & 0 \\
14 & $22 \cdot 77 \pm 1 \cdot 5$ & 0 & 0 \\
\hline
\end{tabular}

of the vagina. Glandular mitosis was maximal on Day 4 of the cycle. As with the mouse, the epithelial tissues of the glands and lumen showed a different pattern of response. Stromal mitosis was low at the start of the cycle and high on Days 5 to 7, about the expected time of implantation in the guinea-pig. Mitosis then declined and remained low for the remainder of the oestrous cycle.

Mating of the animals had no effect on the pattern of mitosis up to Day 6; counts were similar in both groups (Table 2). This result was expected in view of the fact that luteal maintenance is not dependent on copulation in the 
Table 2. Mitosis in uterine tissues of the guinea-pig during early pregnancy

\begin{tabular}{c|l|r|r}
\hline \multirow{2}{*}{ Day of pregnancy } & \multicolumn{3}{|c}{ Mean no. of mitoses \pm S.E. } \\
\cline { 2 - 4 } & \multicolumn{1}{|c}{ Lumen } & \multicolumn{1}{|c}{ Glands } & \multicolumn{1}{c}{ Stroma } \\
\hline 2 & $6 \cdot 0 \pm 1.4$ & $55 \cdot 30 \pm 4 \cdot 20$ & $5 \cdot 67 \pm 0.70$ \\
3 & $7 \cdot 33 \pm 4.5$ & $130.67 \pm 33 \cdot 58$ & $8 \cdot 33 \pm 5 \cdot 40$ \\
4 & 0 & $171.25 \pm 15 \cdot 57$ & $19 \cdot 66 \pm 2 \cdot 24$ \\
5 & 0 & $12.0 \pm 1 \cdot 40$ & $84 \cdot 0 \pm 7.0$ \\
6 & 0 & $14 \cdot 50 \pm 1-25$ & $141 \cdot 50 \pm 68 \cdot 50$ \\
\hline
\end{tabular}

The observations were made on three animals/day of pregnancy.

guinea-pig, and preparation of the uterus for implantation is a normal part of the oestrous cycle.

Effect of exogenous hormones on the uterus of ovariectomized animals

A single injection of $1 \mu \mathrm{g}$ oestradiol-17 $\beta$ had no effect on glandular or stromal cell division but stimulated significant numbers of mitoses in the luminal epithelium. To obtain glandular mitosis required 3 days' treatment with oestrogen (Table 4). Progesterone alone stimulated some cell proliferation in the stroma, although the mitotic counts were very much lower than those

Table 3. Mitosis in uterine tissues of the ovariectomized guinea-pig treated with progesterone, with or without oestradiol-17 $\beta$

\begin{tabular}{|c|c|c|c|c|c|c|c|c|c|c|c|c|c|}
\hline \multirow{2}{*}{ Groups } & \multicolumn{9}{|c|}{ Days } & \multirow{2}{*}{$\begin{array}{l}\text { No. of } \\
\text { animals }\end{array}$} & \multicolumn{3}{|c|}{ Mean no. of mitoses $\pm S . E}$. \\
\hline & 1 & 2 & 3 & 4 & 5 & 6 & 7 & 8 & 9 & & Lumen & Glands & Stroma \\
\hline $\begin{array}{l}1 \\
2 \\
3 \\
4 \\
5 \\
5 \\
6 \\
7 \\
8 \\
9\end{array}$ & $\begin{array}{l}\mathbf{P} \\
\mathbf{P} \\
\mathbf{P} \\
\mathbf{P} \\
\dot{\mathbf{P}} \\
\mathbf{P} \\
\mathbf{P} \\
\mathbf{P}\end{array}$ & $\begin{array}{l}\mathbf{P} \\
\mathbf{P} \\
\mathbf{P} \\
\dot{ } \\
\dot{\mathbf{P}} \\
\mathbf{P} \\
\mathbf{P} \\
\text {. }\end{array}$ & $\begin{array}{l}\mathbf{P} \\
\mathbf{P} \\
\dot{ } \\
\dot{\mathbf{P}} \\
\mathbf{P} \\
\dot{ }\end{array}$ & $\begin{array}{c}\text { Pe } \\
\text { e } \\
\mathbf{e} \\
\mathbf{e} \\
\mathbf{e} \\
\mathbf{P} \\
\dot{.} \\
\dot{.}\end{array}$ & $\begin{array}{l}\mathbf{K} \\
\mathbf{K} \\
\mathbf{K} \\
\mathbf{K} \\
\mathbf{K} \\
\mathbf{K} \\
\mathbf{K} \\
\mathbf{K} \\
\mathbf{K}\end{array}$ & $\begin{array}{l}: \\
: \\
: \\
:\end{array}$ & : & $:$ & $\dot{.}$ & $\begin{array}{l}\mathbf{3} \\
\mathbf{3} \\
\mathbf{3} \\
\mathbf{3} \\
\mathbf{3} \\
\mathbf{4} \\
\mathbf{3} \\
\mathbf{3} \\
\mathbf{3}\end{array}$ & $\begin{array}{l}0 \\
0 \\
0 \\
26 \cdot 41 \pm 3 \cdot 08 \\
33 \cdot 50 \pm 6 \cdot 50 \\
0 \\
0 \\
0 \\
2 \cdot 83 \pm 0 \cdot 17\end{array}$ & $\begin{array}{l}\mathbf{0} \\
\mathbf{0} \\
\mathbf{0} \\
\mathbf{0} \\
\mathbf{0} \\
\mathbf{0} \\
\mathbf{0} \\
\mathbf{0} \\
\mathbf{0}\end{array}$ & $\begin{array}{l}96 \cdot 45 \pm 53 \cdot 84 \\
58 \cdot 77 \pm 27 \cdot 50 \\
0 \\
0 \\
0 \\
8 \cdot 99 \pm 1 \cdot 90 \\
9 \cdot 88 \pm 4.55 \\
7 \cdot 14 \pm 2 \cdot 04 \\
3 \cdot 17 \pm 0 \cdot 17\end{array}$ \\
\hline
\end{tabular}

$\mathrm{P}=2.5 \mathrm{mg}$ progesterone; $\mathrm{e}=100 \mathrm{ng}$ oestradiol-17 $\beta ; \mathrm{K}=$ day of autopsy.

Table 4. Mitosis in uterine tissues of the ovariectomized guinea-pig primed with oestrogen

\begin{tabular}{|c|c|c|c|c|c|c|c|c|c|c|c|c|c|}
\hline \multirow{2}{*}{ Groups } & \multicolumn{9}{|c|}{ Days } & \multirow{2}{*}{$\begin{array}{l}\text { No.of } \\
\text { ani- } \\
\text { mals }\end{array}$} & \multicolumn{3}{|c|}{ Mean no. of mitoses $\pm S . E$. } \\
\hline & 1 & 2 & 3 & 4 & 5 & 6 & 7 & 8 & 9 & & Lumen & Glands & Stroma \\
\hline $\begin{array}{l}10 \\
11 \\
12 \\
13 \\
14 \\
15\end{array}$ & $\begin{array}{l}\mathbf{E} \\
\mathbf{E} \\
\mathbf{E} \\
\mathbf{E} \\
\mathbf{E}\end{array}$ & $\begin{array}{l}\mathbf{E} \\
\mathbf{E} \\
\mathbf{E} \\
\mathbf{E} \\
\mathbf{E} \\
\text {. }\end{array}$ & $\begin{array}{l}\mathbf{E} \\
\mathbf{E} \\
\mathbf{E} \\
\mathbf{E} \\
\mathbf{E} \\
\text {. }\end{array}$ & : & $\begin{array}{l}\text { K } \\
\dot{5} \\
\dot{5} \\
\dot{5}\end{array}$ & $\begin{array}{l}\mathbf{K} \\
\vdots \\
\cdot\end{array}$ & $\dot{\mathbf{K}}$ & $\dot{\mathbf{K}}$ & . & $\begin{array}{l}\mathbf{4} \\
\mathbf{4} \\
\mathbf{5} \\
\mathbf{4} \\
\mathbf{4} \\
\mathbf{4}\end{array}$ & $\begin{array}{r}25 \cdot 61 \pm 3 \cdot 52 \\
21 \cdot 82 \pm 3 \cdot 87 \\
18 \cdot 10 \pm 4.55 \\
8 \cdot 68 \pm 0.33 \\
9 \cdot 14 \pm 1.98 \\
8 \cdot 12 \pm 1.35\end{array}$ & $\begin{array}{l}83 \cdot 25 \pm 7 \cdot 35 \\
33 \cdot 75 \pm 5 \cdot 61 \\
32 \cdot 45 \pm 2 \cdot 26 \\
17 \cdot 80 \pm 2 \cdot 52 \\
2 \cdot 50 \pm 1 \cdot 18 \\
0\end{array}$ & $\begin{array}{l}4 \cdot 14 \pm 0 \cdot 41 \\
8 \cdot 68 \pm 1 \cdot 88 \\
2 \cdot 2 \pm 0 \cdot 38 \\
2 \cdot 52 \pm 0 \cdot 25 \\
0 \\
0\end{array}$ \\
\hline
\end{tabular}

$\mathrm{E}=1.0 \mu \mathrm{g}$ oestradiol. $\mathrm{K}=$ day of autopsy. 
obtained during the cycle (Table 3). The administration of a single dose of oestrogen after 3 days' progesterone treatment elicited a large stromal mitotic response with no response in the epithelial tissues. To obtain this response, it was necessary to continue progesterone injections until at least the day before the oestrogen was given, indicating that in this respect the influence of progesterone does not last for very long.

\section{DISCUSSION}

In the guinea-pig, the pattern of cell proliferation in the uterus in the period preceding implantation is very similar to that already shown in the mouse (Finn \& Martin, 1967) although, as expected, in the former the pattern of mitosis in the cycle is not affected by the occurrence of mating. The endocrine studies show that the high levels of oestrogen in the period preceding implantation stimulate luminal mitosis at the beginning of the oestrous cycle followed by glandular mitosis. Just before implantation, the stromal cells undergo division, following the onset of progesterone secretion by the corpus luteum.

In the ovariectomized animal, it was not possible with progesterone treatment alone to obtain comparable numbers of stromal mitoses to those obtained in the cycle. A small quantity of oestrogen after several days of progesterone, however, did stimulate large numbers of cells to go into mitosis. This suggests that oestrogen is involved in the proliferative changes during the luteal phase of the cycle. It seems that although implantation will occur in the guinea-pig without luteal oestrogen, the cell proliferation in the stroma on Days 5 and 6 of the cycle is dependent on it. Though not obligatory for implantation, therefore, luteal oestrogen probably synergizes with progesterone in the normal preparation of the endometrium. In experimental conditions, presumably, the limited preparation obtained with progesterone alone is sufficient to allow implantation. Deanesly (1960) was able to obtain implantation in guinea-pigs after ovariectomy on Day 3 of pregnancy (day of finding the vaginal plug designated as Day 0 so equivalent to Day 4 in the present experiments) without either exogenous oestrogen or progesterone. Ovariectomy on Day 2, however, was not followed by implantation unless a single dose of progesterone was given after spaying. Deanesly concluded that only a small quantity of progesterone was necessary early in pregnancy to prepare the uterus for implantation.

In the present experiments (Table 3, Groups 3,4 and 5), progesterone did not have a very lasting effect on stromal mitosis although the inhibition of epithelial division lasted longer. Probably this effect of progesterone (which is thought to be associated with differentiation of the epithelium for reception of the blastocyst: Martin \& Finn, 1968) is critical in implantation; lack of stromal mitosis may not be so important. In the mouse, the blastocyst itself stimulates mitosis in the stroma (Finn \& Martin, 1967) at the time of implantation and a similar effect in the guinea-pig may compensate for the lack of hormonally stimulated stromal cell proliferation. 


\section{ACKNOWLEDGMENTS}

We are grateful for financial support from the Medical Research Council, and for technical assistance from Miss Gillian Blair.

\section{REFERENCES}

Chaudhury, R. R. \& Sethi, A. (1970) Effect of an intrauterine contraceptive device on mitosis in the rat uterus on different days of pregnancy. F. Reprod. Fert. 22, 33.

CLARK, B. F. (1971) The effect of oestrogen and progesterone on uterine cell division and epithelial morphology in spayed adrenalectomized rats. $\mathcal{F}$. Endocr. 50, 527.

DeANesLy, R. (1960) Implantation and early pregnancy in ovariectomized guinea-pigs. F. Reprod. Fert. $1,242$.

Finn, C. A. \& Martin, L. (1967) Patterns of cell division in the mouse uterus during early pregnancy. 7. Endocr. 39, 593.

Martin, L. \& Finn, C. A. (1968) Hormonal regulation of cell division in epithelial and connective tissues of the mouse uterus. F. Endocr. 41, 363. 